\title{
Perbandingan kualitas spermatozoa tikus wistar (rattus norvegicus) yang diberi ekstrak buah pare (momordica charantia L) dengan ekstrak biji pepaya (carica papaya $\mathrm{L}$ )
}

\author{
${ }^{1}$ Kyrie E. Wenur \\ ${ }^{2}$ Lusiana Satiawati \\ ${ }^{2}$ Lydia Tendean
}

\author{
${ }^{1}$ Kandidat Skripsi Fakultas Kedokteran Universitas Sam Ratulangi Manado \\ ${ }^{2}$ Bagian Biologi Fakultas Kedokteran Universitas Sam Ratulangi Manado \\ Email: kyriewenur@yahoo.com
}

\begin{abstract}
Male participation in contraception is still lacking. Pare (Momordica charantia L) is known having an inhibitory effect spermatogenesis and seeds of papaya (Carica papaya L) contain the alkaloid compounds that are anti-fertility, both can be used as a male contraceptive. The purpose of this study was to determine sperm quality comparison Wistar rats (Rattus norvegicus) were given a fruit extract of pare (Momordica charantia L) with the seed extract of papaya (Carica papaya L). The research used a completely randomized experimental design. There are nine samples of Wistar rats (Rattus norvegicus) males were divided into three groups and one group consisting three Wistar rats. Over the past 50 days, extracts of pare (Momordica charantia L) is given to the group 1 at $70 \mathrm{mg} / \mathrm{kg} / \mathrm{day}$, while in the group 2 given seed extract of papaya (Carica papaya $\mathrm{L}$ ) of $70 \mathrm{mg} / \mathrm{kg} / \mathrm{day}$ and the control group was given no treatment. The results showed significant differences in sperm motility among the treatment groups 1 with extract of bitter melon fruit (Momordica charantia $\mathrm{L}$ ) and 2 treatment groups with the extract of papaya seeds (Carica papaya $\mathrm{L})$, namely a decrease in sperm motility $(\mathrm{p}=0.002)$. Conclusion, the fruit extract of bitter melon (Momordica charantia L) and seed extract of papaya (Carica papaya $\mathrm{L}$ ) affects the quality of spermatozoa.
\end{abstract}

Keywords: pare, papaya seeds, quality of spermatozoa.

\begin{abstract}
Abstrak: Partisipasi pria dalam menggunakan alat kontrasepsi masih sangat kurang. Pare (Momordica charantia L) diketahui memiliki efek penghambatan spermatogenesis dan biji pepaya (Carica papaya L) mengandung senyawa alkaloid yang bersifat antifertilitas, keduanya dapat digunakan sebagai bahan kontrasepsi pria. Tujuan penelitian ini adalah mengetahui perbandingan kualitas spermatozoa tikus wistar (Rattus norvegicus) yang diberi ekstrak buah pare (Momordica charantia L) dengan ekstrak biji pepaya (Carica papaya L). Penelitian ini menggunakan metode penelitian eksperimental dengan menggunakan rancangan acak lengkap. Sampel yang digunakan adalah sembilan tikus wistar (Rattus norvegicus) jantan yang dibagi menjadi tiga kelompok dan satu kelompok terdiri dari tiga ekor tikus wistar. Selama 50 hari, ekstrak buah pare (Momordica charantia L) diberikan pada kelompok perlakuan 1 sebesar $70 \mathrm{mg} / \mathrm{kgBB}$ per hari, sedangkan pada kelompok perlakuan 2 diberikan ekstrak biji pepaya (Carica papaya $\mathrm{L}$ ) sebesar $70 \mathrm{mg} / \mathrm{kgBB}$ per dan kelompok kontrol tidak diberikan perlakuan. Hasil penelitian menunjukan adanya perbedaan signifikan pada motilitas spermatozoa antara kelompok perlakuan 1 dengan pemberian ekstrak buah pare (Momordica charantia L) dan kelompok perlakuan 2 dengan pemberian ekstrak biji pepaya (Carica papaya $\mathrm{L}$ ) yaitu penurunan motilitas spermatozoa $(\mathrm{p}=0,002)$.

Kesimpulan, ekstrak buah pare (Momordica charantia L) dan ekstrak biji pepaya (Carica papaya L) berpengaruh terhadap kualitas spermatozoa.
\end{abstract}

Kata kunci: buah pare, biji pepaya, kualitas spermatozoa 
Pertambahan jumlah penduduk di Indonesia dari tahun ke tahun terus meningkat secara tajam. Oleh karena itu pemerintah berupaya untuk menekan laju pertumbuhan penduduk dengan salah satu program yang dikenal dengan Keluarga Berencana (KB). ${ }^{1}$

Data Badan Kependudukan dan Keluarga Berencana Nasional (BKKBN) menunjukkan bahwa pada tahun 2013 dilihat dari jenis kelamin, metode kontrasepsi perempuan yang digunakan jauh lebih besar dibanding dengan metode kontrasepsi laki-laki. Metode perempuan sebesar 93,66 \% sementara metode lakilaki hanya sebesar 6,34 \%. Hal ini menunjukkan bahwa partisipasi laki-laki dalam menggunakan alat kontrasepsi masih sangat kecil. Penggunaan alat kontrasepsi masih dominan dilakukan oleh perempuan. ${ }^{2}$

Salah satu tanaman tradisional yang digunakan sebagai kontrasepsi pria adalah buah pare (Momordica charantia L). Sejak diketahui bahwa tanaman pare berkhasiat terhadap kesehatan maka beberapa peneliti berusaha mengetahui dan mengisolasikan bahan yang terkandung dalam tanaman pare. Sebagai tumbuhan bangsa cucurbitaceae, pare juga mengandung bahan yang tergolong dalam glikosida triterpen atau kukurbitasin. ${ }^{3}$ Senyawa aktif kukurbitasin diduga bekerja menghambat perkembangan sel spermatogenik melalui efek sitotosik dan melalui efek hormonal. ${ }^{4}$ Hasil penelitian yang dilakukan oleh Kusuma menyatakan bahwa pemberian ekstrak buah pare pada tikus jantan selama satu siklus spermatogenesis dapat menurunkan motilitas spermatozoa dan meningkatkan morfolgi abnormal spermatozoa tikus jantan strain wistar. ${ }^{5}$

Tanaman tradisional lain juga digunakan sebagai kontrasepsi pria yaitu biji pepaya (Carica papaya L). Pepaya merupakan jenis tanaman yang bernilai ekonomis. Hampir semua bagian tanaman papaya (dari daun sampai akarnya) dapat dimanfaatkan dalam kehidupan manusia, namun manfaat biji pepaya masih belum banyak diketahui masyarakat kecuali sebagai bibit. Penelitian dari Satriyasa membuktikan bahwa biji pepaya mempunyai efek antifertilitas. Biji pepaya mengandung senyawa alkaloid yang bersifat antifertilitas dan dapat digunakan sebagai bahan kontrasepsi pria. ${ }^{6}$

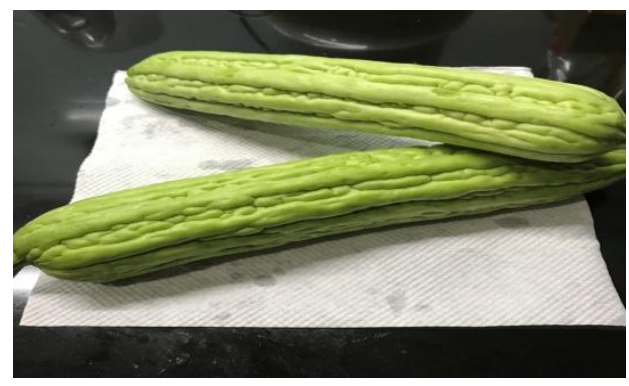

Gambar 1. Buah pare (Momordica charantia $\mathrm{L}$ )

a

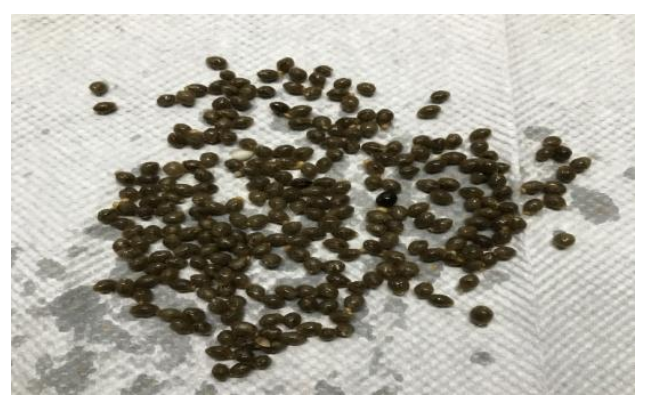

Gambar 2. Biji papaya (Carica papaya L)

\section{METODE PENELITIAN}

Penelitian ini merupakan penelitian eksperimental dengan pendekatan post test only control group design. Penelitian dilakukan di Laboratorium Biologi Fakultas Kedokteran Universitas Sam Ratulangi Manado dari bulan September sampai November 2016. Sampel yang digunakan pada penelitian ini adalah sembilan ekor tikus wistar jantan (Rattus norvegicus) berumur 12 - 14 minggu dengan berat badan 150 - 200 gram dan dibagi menjadi tiga kelompok, yaitu kelompok kontrol $\left(\mathrm{P}_{0}\right)$ tidak diberikan perlakuan, kelompok perlakuan $1 \quad\left(\mathrm{P}_{1}\right)$ diberikan larutan ekstrak buah pare dengan dosis $70 \mathrm{mg} / \mathrm{kgBB}$ per hari, kelompok perlakuan $2\left(\mathrm{P}_{2}\right)$ diberikan larutan ekstrak biji pepaya dengan dosis $70 \mathrm{mg} / \mathrm{kgBB}$. Perlakuan dilakukan selama 50 hari.

Pada hari ke-51, hewan coba 
diterminasi menggunakan disecting kit untuk mengambil cauda epididimis. Selanjutnya cauda epididimis dimasukkan ke dalam cawan petri dan ditetesi NaCL $0,9 \%$ sebanyak 5 tetes. Suspensi sperma dari cauda epididimis ini yang digunakan untuk pengamatan kualitas spermatozoa hewan coba meliputi konsentrasi spermatozoa, motilitas spermatozoa dan morfologi spermatozoa.

Uji normalitas dan homogenitas dilakukan untuk mengetahui distribusi data, kemudian setelah data diketahui berdistribusi normal dan homogen, uji komparabilitas antar kelompok penelitian dilakukan dengan uji $\mathrm{T}$ independen.

\section{HASIL PENELITIAN}

Setelah dilakukan penelitian selama 50 hari didapatkan hasil rerata konsentrasi, motilitas dan morfologi spermatozoa masing-masing kelompok (Tabel 1).
Pada Tabel 2 dapat dilihat bahwa terdapat perbedaan signifikan pada konsentrasi spermatozoa antara kelompok kontrol dan kelompok perlakuan 1 $(\mathrm{p}<0,05) ;$ terdapat perbedaan signifikan pada motilitas spermatozoa antara kelompok kontrol dan kelompok perlakuan 1 ( $\mathrm{p}<0,05)$; terdapat perbedaan signifikan pada morfologi spermatozoa antara kelompok kontrol dan kelompok perlakuan $1(\mathrm{p}<0,05)$.

Pada Tabel 3 dapat dilihat bahwa tidak terdapat perbedaan signifikan pada konsentrasi spermatozoa antara kelompok kontrol dan kelompok perlakuan 2 ( $>>0,05)$; terdapat perbedaan signifikan pada motilitas spermatozoa antara kelompok kontrol dan kelompok perlakuan 2 ( $\mathrm{p}<0,05)$; terdapat perbedaan signifikan pada morfologi spermatozoa antara kelompok kontrol dan kelompok perlakuan $2(\mathrm{p}<0,005)$.

Tabel 1. Rerata konsentrasi, motilitas dan morfologi spermatozoa

\begin{tabular}{cccccc}
\hline Kelompok & Konsentrasi & \multicolumn{2}{c}{ Motilitas (\%) } & \multicolumn{2}{c}{ Morfologi (\%) } \\
\cline { 3 - 6 } sampel & $\mathbf{( \times 1 0} / \mathbf{m l})$ & Normal & Abnormal & Normal & Abnormal \\
$\mathrm{P}_{0}$ & 46,66 & 67,33 & 32,66 & 88,66 & 11,33 \\
$\mathrm{P}_{1}$ & 34 & 22,33 & 77,66 & 52 & 48 \\
$\mathrm{P}_{2}$ & 41,33 & 38,33 & 61,66 & 63,66 & 36,33 \\
\hline
\end{tabular}

Tabel 2. Pengujian Rerata Kualitas Spermatozoa Kelompok Kontrol Terhadap Kelompok Perlakuan 1 Dengan Uji T.

\begin{tabular}{lccc}
\hline \multicolumn{1}{c}{ Kualitas spermatozoa } & $\mathbf{P}_{\mathbf{0}}$ & $\mathbf{P}_{\mathbf{1}}$ & Nilai $\mathbf{p}$ \\
\hline Konsentrasi & $46,66 \times 10^{6}$ & $34 \times 10^{6}$ & 0,004 \\
Motilitas normal & $67,33 \%$ & $22,33 \%$ & 0,000 \\
Morfologi normal & $88,66 \%$ & $52 \%$ & 0,002 \\
\hline
\end{tabular}

Tabel 3. Pengujian Rerata Kualitas Spermatozoa Kelompok Kontrol Terhadap Kelompok Perlakuan 2 Dengan Uji T.

\begin{tabular}{lccc}
\hline \multicolumn{1}{c}{ Kualitas spermatozoa } & $\mathbf{P}_{\mathbf{0}}$ & $\mathbf{P}_{\mathbf{2}}$ & Nilai $\mathbf{p}$ \\
\hline Konsentrasi & $46,66 \times 10^{6}$ & $41,33 \times 10^{6}$ & 0,142 \\
Motilitas normal & $67,33 \%$ & $38,33 \%$ & 0,001 \\
Morfologi normal & $88,66 \%$ & $63,66 \%$ & 0,000 \\
\hline
\end{tabular}


Tabel 4. Pengujian Rerata Kualitas Spermatozoa Kelompok Perlakuan 1 Terhadap Kelompok Perlakuan 2 Dengan Uji T.

\begin{tabular}{lccc}
\hline \multicolumn{1}{c}{ Kualitas spermatozoa } & $\mathbf{P}_{\mathbf{1}}$ & $\mathbf{P}_{\mathbf{2}}$ & Nilai p \\
\hline Konsentrasi & $34 \times 10^{6}$ & $41,33 \times 10^{6}$ & 0,082 \\
Motilitas normal & $22,33 \%$ & $38,33 \%$ & 0,002 \\
Morfologi normal & $52 \%$ & $63,66 \%$ & 0,105 \\
\hline
\end{tabular}

Pada Tabel 4 dapat dilihat bahwa tidak terdapat perbedaan signifikan pada konsentrasi spermatozoa antara kelompok perlakuan 1 dan kelompok perlakuan 2 ( $>0,05)$; terdapat perbedaan signifikan pada motilitas spermatozoa antara kelompok perlakuan 1 dan kelompok perlakuan $2 \quad(\mathrm{p}<0,05)$; tidak terdapat perbedaan signifikan pada morfologi spermatozoa antara kelompok perlakuan 1 dan kelompok perlakuan $2(\mathrm{p}>0,05)$

\section{BAHASAN}

Pada penelitian ini menunjukan bahwa kelompok perlakuan 1 berpengaruh terhadap kualitas spermatozoa yaitu penurunan konsentrasi, motilitas, dan morfologi spermatozoa sedangkan kelompok perlakuan 2 juga berpengaruh terhadap kualitas spermatozoa yaitu penurunan motilitas dan morfologi spermatozoa. Hasil analisis perbandingan kualitas spermatozoa antara kelompok perlakuan 1 dan kelompok perlakuan 2 menunjukan ada perbedaan signifikan pada motilitas tetapi tidak pada konsentrasi dan morfologi.

Terdapat perbedaan signifikan pada konsentrasi, motilitas, dan morfologi spermatozoa pada kelompok perlakuan 1 terhadap kelompok kontrol yang tidak diberikan perlakuan karena pare mempunyai kandungan kukurbitasin yang dapat menghambat pertumbuhan dan perkembangan sel. Hambatan ini mungkin disebabkan oleh terhambatnya sumber energi dengan demikian sel spermatogenik tidak dapat berkembang membentuk spematozoa. ${ }^{7,8}$ Dibuktikan dalam penelitan Dixit bahwa konsentrasi RNA total dan konsentrasi protein testis menurun sangat nyata pada anjing yang diberi ekstrak pare. Dari kedua parameter tersebut saling berkaitan karena jika ada salah satu parameter yang terganggu akan menyebabkan pergerakan yang tidak normal. Kecepatan spermatozoa merupakan manifestasi bahwa spermatozoa tersebut mempunyai daya motilitas. ${ }^{9}$

Terdapat juga perbedaan signifikan pada motilitas dan morfologi spermatozoa pada kelompok perlakuan 2 terhadap kelompok kontrol yang tidak diberikan perlakuan. Penelitian sebelumnya menunjukkan bahwa peningkatan morfologi spermatozoa abnormal terjadi karena ekstrak biji pepaya menyebabkan terjadinya abnormalitas organela sel pada bagian leher spermatozoa, yaitu vakuolisasi pada mitokondria. Hal ini menyebabkan fungsi mitokondria dalam menghasilkan energi menjadi tidak maksimal, dan dengan demikian berpengaruh pada motilitas spermatozoa. ${ }^{10}$

Hasil penelitian ini menunjukan terjadinya penurunan kualitas spermatozoa setelah pemberian ekstrak buah pare dan ekstrak biji pepaya pada masing-masing perlakuan. Hal ini sesuai dengan beberapa penelitian sebelumnya yang menyebutkan bahwa pemberian ekstrak buah pare dan ekstrak biji pepaya menunjukan adanya penurunan kualitas spermatozoa. ${ }^{4,5,6,10}$

\section{SIMPULAN}

1. Terdapat pengaruh pemberian ekstrak buah pare (Momordica charantia L) terhadap kualitas spermatozoa yaitu konsentrasi, motilitas, dan morfologi spermatozoa.

2. Terdapat pengaruh pemberian ekstrak biji pepaya (Carica papaya L) 
terhadap kualitas spermatozoa yaitu motilitas dan morfologi.

3. Terdapat perbandingan antara ekstrak buah pare (Momordica charantia L) dengan ekstrak biji pepaya (Carica papaya L) terhadap kualitas spermatozoa yaitu penurunan motilitas spermatozoa.

\section{DAFTAR PUSTAKA}

1. Badan pusat statistik. Proyeksi pertumbuhan penduduk menurut provinsi 2010 2035.2014. Dapat di akses https://www.bps.go.id/linkTabelStatis /view/id/1274

2. Pusat Data \& Informasi Kementrian Kesehatan RI. 2014. Dapat di akses di http://www.depkes.go.id/download.p $\mathrm{hp}$ ?file=download/pusdatin/infodatin/ infodatin-harganas.pdf

3. Grover JK, Yadav SP. Pharmacological actions and potential uses of Momordica charantia: a review, $J$ Ethnopharmacol. 2004; 93(1); 12332.

4. Mitayani. Pengaruh Pemberian EkstrakPare (Momordica charantia L) Terhadap Jumlah Spermatozoa, Diameter Tubulus Seminiferus dan Berat Testis Tikus Jantan Strain Wistar Sebagai Bahan Kontrasepsi Alamiah. [Tesis]. Universitas Padjadjaran; 2009.
5. Kusuma R. Pengaruh PemberianEkstrak Buah Pare (Momordica Chorantia L ) Terhadap Kualitas Spermatozoa Tikus Jantan Strain Wistar [Tesis].[Studi Ilmu Biomedik]: Universitas Andalas; 2008.

6. Satriyasa BK, Pangkahila WI.Pengaruh fraksi methanol ekstrak dan heksan biji papaya (Carica papaya L) terhadap proses spermatogenesis mencit jantan (Mus musculus). Veteriner. 2010; 11(1): 36-40.

7. Hernawati. Potensi buah pare(Momordica Chorantia L ) sebagai herbal antifertilitas. [Skripsi]. Universitas Pendidikan Indonesia; 2011.

8. Astuti Y, Fitriana S, Rahuyu NS.Pengaruh Pemberian Ekstrak Pare (Momordica charantia L) Terhadap Motilitas dan Morfologi Sperma Mencit. Mutiara Medika. 2009; 9(1): 26-32.

9. Salisbury, G.W dan Vandemark, N.L.Fisiologi Reproduksi Dan Inseminasi Buatan Pada Sapi. Diterjemahkan oleh Djanur, R. Gadjah Mada University Press.

10.Lohiya NK, Goyal RB, JayaprakashD, Ansari AS, dan Sharma S. Antifertility Effects of Aquoeous Extract of Carica papaya Seed in Male Rats. Planta Med. 1999; 60, 400-404. 